Holburt Waring. The Farm is intended to provide young surgeons with opportunities of extending our knowledge of the biological processes which underlie the art of surgery. Already a series of experimental inquiries has been set on foot to determine how far surgical methods can be employed for the cure or relief of the graver forms of pulmonary tuberculosis. In his opening address, Sir Holburt Waring outlined some of the clinical conditions which require experimental elucidation. He cited particularly the grave mortality which still attends intestinal obstruction and the need for further study of the condition known as surgical shock. The Research Farm, which is $16 \frac{1}{2}$ miles from Charing Cross, is the gift of Sir Buckston Browne, a distinguished London surgeon and a fellow of the Royal College of Surgeons. Rather more than two years ago he gave $£ 100,000$ to his College in order that it might be able to add a research station in the country to the experimental laboratories already established in connexion with the Hunterian Museum in Lincoln's Inn Fields.

As is well known, John Hunter, the celebrated surgeon of the eighteenth century, carried on his experimental work at his farm at Earl's Court. Sir Buckston Browne wished to present a modern representation of Hunter's Earl's Court Farm to his College and chose a site in the parish of Downe, Kent, adjacent to the home of Charles Darwin. It will be remembered that in 1928 Sir Buckston purchased Darwin's home, Down House, and after restoring and endowing it, presented it to the British Association. The Research Farm is built on land which adjoins the gardens and grounds of Down House. Sir Buckston Browne has thus established side by side in Darwin's parish two bodies which encourage research, namely, the British Association for the Advancement of Science and the Royal College of Surgeons of England. Dr. O. J. R. Howarth is resident officer at Down House, while Sir Arthur Keith is in charge of the Buckston Browne Research Farm.

\section{Cancer Research}

THE tenth annual report of the British Empire Cancer Campaign notices a considerable variety of investigations into the nature, cause and treatment of cancer, which are being carried on under its auspices in different parts of the world. Three of the results obtained especially are of general interest. At the Cancer Hospital, Prof. E. L. Kennaway, Dr. J. W. Cook and their colleagues have now isolated the substance (or one of the substances) to which tar owes its peculiar carcinogenic properties: it proves to be 1:2-benzpyrene. No evidence was obtained of the presence of the dibenzanthracene which the same workers have synthesised and shown to be nearly equally active, and, along with Prof. E. C. Dodds, to have a remarkable influence on the sexual cycle in animals. It remains to be discovered whether these or similar substances are ever produced in the body and so form the intermediaries whereby chronic irritation and injury give rise to tumours. At the Middlesex Hospital, Prof. J.
McIntosh has made the notable discovery that some at least of the connective tissue tumours produced in fowls by tar can be transmitted by a filtrable agent. The experimental growths thus come into line with the natural bird tumours which have been so much studied. No clear mammalian tumour has yet been shown to be certainly filtrable.

\section{A Virus from Influenza Patients}

The causation of epidemic influenza has proved a perplexing problem for the bacteriologist. Of the bacterial organisms associated with the disease, Pfeiffer's influenza bacillus, the most frequent, and others do not appear to be capable of reproducing the cardinal features of the disease, but only some of the secondary symptoms. Another difficulty encountered is the insusceptibility of most animals to human influenza, the so-called influenzas of animals being distinct from the human. Latterly, attempts have been made to detect a virus in the disease, hitherto with little or no success, but in a recent communication, Smith, Andrewes and Laidlaw describe results obtained with ferrets (Lancet, July 8, p. 66). A febrile disease is produced in ferrets by the intranasal instillation of filtrates of throat washings obtained from influenza patients, which is transmissible serially in ferrets either by contact or by intranasal instillation of virus material from infected ferrets. Filtration was conducted through 'Gradocol' membranes so that the filtrate is bacteriafree. Throat-washings from healthy persons and influenza convalescents caused no illness in ferrets. The disease in ferrets has some likeness to human influenza, with nasal and pulmonary catarrh and occasionally a relapse. The blood-serum of a ferret that has recovered, and also that of recovered human cases, neutralises the virus. The virus of swine influenza, described by Shope, has a close antigenic relationship with the influenza virus, and induces a disease in ferrets very like that produced with the influenza virus. A prima facie case has indirectly been made out for an attempt to transfer the ferret disease back again to man, and a technique has been discovered which can be exploited fruitfully when the next human epidemic occurs.

\section{Massive Radium Unit for Treatment}

Ix may be recalled that the Radium Committee decided last year to withdraw and dismantle the four-gram radium 'bomb' used for massive radiation at Westminster Hospital. Some doubt was expressed at the time of the wisdom of this step, but a conference called by the Royal Colleges of Physicians and Surgeons endorsed the policy, at the same time appointing a committee of experts to reconsider the case for mass radiation. After visits to radium treatment centres abroad, the committee reported that it is desirable that a radium unit of not less than five grams should be established, so that research can be undertaken on the value of what is best termed 'beam' therapy. For this purpose, a representative governing body with Sir Frederick Gowland Hopkins as chairman was constituted. After negotia- 
tion, the Belgian organisation, the Union Minière du Haut-Katanga, offered the loan of five grams of radium for two years free of cost except for insurance, with an additional five grams at a later date if considered necessary. An executive research committee has been formed with Prof. J. C. McLennan as chairman. The place for the research is the London Radium Institute, Ridinghouse Street, Portland Place, London, W.1, which has generously placed the whole of the accommodation necessary at the disposal of the governing body.

\section{Alcoholism in Medieval England}

Ат a meeting of the Society for the Study of Inebriety and Drug Addiction on July 11, a paper on alcoholism in medieval England was read by Dr. J. D. Rolleston, who said that the chief sources of information concerning the prevalence of alcoholism in the Middle Ages were lay writers, especially poets, historians and ecclesiastics, whereas little was to be gleaned from contemporary medical works. In the Middle Ages, distilled liquors were unknown as a convivial beverage and alcoholism was due mainly to indulgence in ale and to a less extent in wine. Inebriety was widely spread in all classes of society, but predominated among the clergy, in spite of the protests of leading ecclesiastics such as Anselm, Bede, Boniface, Dunstan and Wycliffe, and among the university students. The medieval publican had a bad reputation for fraud and dishonesty, while the tavern was often regarded as a place of ill-repute. Alcoholism during the Middle Ages in England, as elsewhere, resembled in many ways the alcoholism of classical antiquity, which Dr. Rolleston discussed in a previous paper before the Society (see NaturE, Oct. 23, 1926, p. 601). Legislation dealing with drunkenness or control of the liquor trade was practically unknown in the ancient world, whereas taxation of drink, reduction in the hours of sale and the number of taverns and other restrictions were introduced in the Middle Ages. The absence of syphilis in both ages was noteworthy in view of the fact that alcohol was such a frequent incentive to exposure to infection and was liable to aggravate the disease when once it was acquired.

\section{Atmospheric Pollution in Great Britain}

IN a paper read before the National Smoke Abatement Society on July 14, Sir Frank Baines, the well-known architect, dealt at some length with the effects of atmospheric pollution on buildings, vegetation and public health. While he was Director of Works and Buildings at H.M. Office of Works, Sir Frank had exceptional opportunities for studying the effects on national buildings of the various impurities in the atmosphere due to the burning of coal, and for estimating what it costs the nation in deterioration of buildings and repairs due to this cause alone. $\mathrm{He}$ gave this cost for the last twentyfive years as a minimum of 55 million pounds sterling, and contrasted this with the niggardly parsimony of H.M. Treasury in its provision of funds for the investigation of the problem and the institution of methods of prevention. All legislation hitherto devised to cope with the contamination of the atmosphere has failed to deal with sulphur gases, the greatest destructive agents of all. To these agents Sir Frank attributed the rapid deterioration of the stonework of the Houses of Parliament, Westminster Abbey and other great national buildings. Sedimentary stones are peculiarly subject to the attack of atmospherie sulphuric acid formed by the action of moisture on sulphur effluents : but even the surface of granite in buildings is completely destroyed by this acid. Bricks, cement, lime mortars, metal, paints and composite materials of all kinds, vary in susceptibility to this attack, but the general effect is to make it probable that the readings of history in all our national monuments will be rendered unintelligible. The mass of evidence collected by Sir Frank Baines will be invaluable to the serious student of the problem of atmospheric pollution and it is gratifying to know that the National Smoke Abatement Society proposes to make this important paper available to the public.

\section{Memorials in Westminster Abbey}

JUst after the commemoration on April 22-24 of the centenary of Richard Trevithick, to whom there is a window in Westminster Abbey, Eng.-Capt. E. C. Smith, in a letter published in the Times of April 29, directed attention to the removal some time ago, from the north aisle, of three memorial windows, to Joseph Locke, Robert Stephenson and Sir William Siemens respectively. It came as a surprise to many unfamiliar with the memorials in the Abbey to learn that these three windows were no longer in place and further correspondence on the matter has since appeared in Engineering. It is known that it is a good many years since the windows were removed to make way for others, and in a letter in Engineering of July 7 , the Dean of Westminster, the Rev. W. Foxley Norris, writes: "The windows in question were removed before my time and $I$ know nothing of the circumstances, and we are at this moment taking the necessary measures for their replacement, which was, I understand, intended by my predecessor." As the windows to Locke, Stephenson and Siemens were erected mainly through the efforts of contemporary engineers and men of science, in recognition of their high professional standing, it is most desirable from every point of view that the windows should be re-erected, and we trust the Dean and Chapter will be able to find a reasonable solution of the problem with which they are faced

\section{Thermal Convection Air Currents and Gliding}

THE recent spell of hot sunny weather in England made possible a series of experiments concerning the existence and magnitude of thermal convection currents in the air, arising from the reflection of heat from the sun-baked earth. Mr. G. E. Collins, instructor at the British Gliding Association's Summer School at Huish Hill, near Marlborough, using a two-seater glider of the B.A.C.VII type, was towed 